\title{
Economic solidarity as a constitutional principle of the Russian economic system
}

\section{E. M. Yakimova ${ }^{1}$}

${ }^{1}$ Baikal State University, 11 Lenin str., Irkutsk, Irkutsk region 664003, Russia

DOI: 10.18255/1996-5648-2021-4-568-573

Research article Full text in Russian

The constitutional regulation of the economic system of modern Russia has undergone changes in connection with the amendments to the Constitution of Russia in 2020 aimed at establishing the ideological and value component of interaction within the system business-society-state. One of the new constitutional principles was the movement towards economic solidarity. However, the content of this category to date does not have a complete understanding and unambiguous interpretation, while the category has received a wide understanding within the framework of sociology, philosophy, economics. It has been established that economic solidarity is a category of legal, has features of constitutional value and constitutional principle.

Keywords: constitutional principle; constitution; solidarity; economic basis; economic relations; rule of law; constitutional value; communicative principle

\section{INFORMATION ABOUT AUTHORS}

Yakimova, EkaterinaM.

E-mail: yakimova_katerin@mail.ru

Cand. Sc. (Jurisprudence), Associate Professor, Associate Professor of the Chair of Legal Support of National Security 


\section{Экономическая солидарность как конституционный принцип экономической системы России}

Е. М. Якимова ${ }^{1}$

${ }^{1}$ Байкальский государственный университет, ул. Ленина, 11, Иркутск, 664003, Российская Федерация

DOI: 10.18255/1996-5648-2021-4-568-573

УДК 342.417

Научная статья

Полный текст на русском языке

Конституционное регулирование экономической системы современной России претерпело изменения в связи с внесением в Конституцию России поправок в 2020 г., направленных на установление идейно-ценностной компоненты взаимодействия внутри интаэросистемы бизнес - общество - государство. Одной из новых конституционных установок стало движение к достижению экономической солидарности. Вместе с тем содержательное наполнение данной категории до настоящего времени не имеет полного понимания и однозначного толкования, при этом категория получила широкое осмысление в рамках социологии, философрии, экономики. Установлено, что экономическая солидарность выступает категорией правовой, имеет черты конституционной ценности и конституционного принципа.

Ключевые слова: конституционный принцип; конституция; солидарность; экономическая основа; экономические отношения; норма права; конституционная ценность; коммуникативный принцип

\section{ИНФОРМАЦИЯ ОБ АВТОРАХ}

Якимова, Екатерина Михайловна

E-mail: yakimova_katerin@mail.ru

Кандидат юридических наук, доцент, доцент кафедры правового обеспечения национальной безопасности

Вопрос о субстанциональных характеристиках такой категории, как «конституционная ценность», и ее преломлении в текстах правовых актах является весьма сложным и многоаспектным. Безусловно, конституционные ценности всегда являлись основой для фрормирования модели конституционного развития и находили отражение в различных нормах конституции [1-2], причем не только в положениях, описывающих основы конституционного строя. Вместе с тем в современной России наблюдается тенденция на включение в текст Конституции категорий, имеющих признаки ценно- 
Якимова Е. М.

сти, однако не в полной мере являющиеся правовыми категориями. Ранее подобного рода положения, причем разнородные, находили достойное место в преамбуле, что гармонично сочеталось с отсутствием у нее юридического значения. Так, в преамбуле Конституции «одновременно можно обнаружить как идеи либерального и универсального характера..., так и концепцию социальной солидарности», причем «второго в преамбуле явно больше» [3, с. 72]. Однако в результате конституционной реформы в основном тексте Конституции России появилось большое число конституционных ценностей (например, в статье 75.1 Конституции обозначены такие ценности, как создание условий для устойчивого экономического роста страны и повышения благосостояния граждан, для взаимного доверия государства и общества, гарантированность защиты достоинства граждан и уважение человека труда, сбалансированность прав и обязанностей гражданина, социальное партнерство, экономическая, политическая и социальная солидарность). Конституционная регламентация указанных категорий, как представляется, требует оценки с позиции их места в системе права: становятся ли включенные в Конституцию ценности принципами права либо они таковыми не являются. Дополнение текста Конституции России социальными ценностями не должно рассматриваться как явление техническое, поскольку, становясь нормой права конституционного значения, подобные положения приобретают статус обязательного правила поведения, имеющего специфические признаки, включая специальный механизм защиты. Особенно четкого ответа на данный вопрос требует бизнес-сообщество, поскольку "новые» положения Конституции могут существенно скорректировать основы функционирования интаэросистемы бизнес - общество - государство [4].

\section{Понимание конституционных принципов права}

Для ответа на данный вопрос необходимо четко определиться с пониманием принципа права. Представляется обоснованным полагать, что принципы права не являются «самостоятельными структурными подразделениями системы права, поскольку принципы права всегда так или иначе выражены в нормах права и сами выступают в качестве основных, исходных норм при регулировании общественных отношений. Не случайно слово «принцип» определяется в отдельных словарях не только как руководящая идея, но и как «основное правило поведения» [5, с. 159]. Таким образом, принцип права представляет собой норму права, обладающую определенными характеристиками исходной нормы, составляющую основу системы права и правового регулирования общественных отношений [5, с. 160], при этом принципы права абстрактны [6, с. 27], они не обозначают конкретики и частностей.

Одной из типологий является выделение конституционных, межотраслевых (не все межотраслевые принципы являются конституционными), отраслевых принципов права. Представляется, что понимание конституционных принципов лежит более глубоко, чем их закрепление в конституциях. Появление того или иного принципа в конституциях имеет не техническое, а аксиологическое значение, поэтому конституционные принципы 
столь многогранны и имеют, чаще всего, не только правовое, но и политическое значение [7, с. 218], что обусловлено тем, что любая конституционная ценность имеет признаки «социокультурной сущности, политикоправового содержания и метаюридической фрормы» [8, с. 23]. Конституционный принцип и конституционная ценность связаны между собой как фрорма и содержание (через аксиологическую направленность правовой нормы).

Таким образом, закрепление в тексте Конституции России новых норм может порождать появление как новых конституционных норм, так и новых конституционных принципов права, основанных на существовавших или выявленных конституционных ценностях. Оценка нового положения в конституционном тексте как нормы права или принципа права лежит в определении его идейно-ценностной компоненты и технико-юридического значения.

\section{Содержание экономической солидарности как конституционного принципа экономической системы Российской Федерации}

Экономическая система, как представляется, наиболее чувствительна к изменению правового регулирования в силу того, что подобного рода изменения имеют для этой системы практическое значение. Поэтому обратим внимание на те «новые» конституционные ценности, которые непосредственно относятся именно к экономической системе общества: на создание условий для устойчивого экономического роста страны и повышения благосостояния граждан, социальное партнерство, экономическую солидарность.

Из всех «новых» конституционных принципов экономической системы Российской Федерации особый интерес представляет экономическая солидарность, поскольку отдельные ее проявления в виде ответственного ведения бизнеса еще до включения в текст Конституции имели законодательное закрепление, однако после включения соответствующих конституционных положений будут, безусловно, наполнены дополнительным содержанием.

Экономическая солидарность также является примером должного поведения участников экономических отношений. В тексте Закона о поправке к Конституции России 2020 г. категория «солидарность» употребляется два раза: в ч. 6 ст. 75 в контексте определения основ функционирования пенсионной системы через соблюдение принципов всеобщности, справедливости и солидарности поколений, а также в ст. 75.1 применительно к обеспечению экономической, политической и социальной солидарности. Закрепление солидарности в качестве конституционного положения обусловлено тем, что «обеспечение совместных действий людей, т. е. их взаимодополнения и согласования, - важнейшая задача государства и вообще государственности» [9, с. 142], причем «успех процесса согласования во многом определяется соотношением интересов - экономических, социальных, культурных и т. д.» $[10$, с. 156$]$.

Солидарность - категория многоаспектная. Близкими по смыслу являются категории «сплоченность», «доверие», «взаимодействие», «сотруд- 
Якимова Е. М.

ничество», «сопереживание», «интеграция». Солидарность рассматривают как моральную ценность [11, с. 255], онтологический «якорь» естественного права [12, с. 133], гуманистическое основание культуры доверия [13, с. 19], парадигмы развития современного постиндустриального общества [14, с. 9]. В целях настоящего исследования особое значение имеет такая субстанциональная характеристика солидарности, как наличие момента «приведения в согласие векторов активности различных социальных акторов» [15, с. 85], поскольку данное действие отражает достижение равновесного состояния общественной системы на определенном временном этапе, что позволяет обеспечить равновесие общественной системы не только как состояния, но и достижения сходящихся сил в рамках силового многоугольника. Государство, объявляя солидарность конституционной ценностью, берет на себя определенные социальные обязательства, однако при фрормировании и реализации государственной политики для реализации данной цели стоит учитывать, что «правовое демократическое государство должно регламентировать социальные отношения, стараясь не перейти ту критическую черту, за которой наступает их огосударствление, ущемление свободы, активности, инициативности, самостоятельности, подавление личности и гражданского общества политической элитой и бюрократическим аппаратом под предлогом всеобщей социальной солидарности и установление тоталитарного политического режима» [14, с. 403]. Следовательно, экономическая солидарность является скорее не предписанным правилом поведения, а его ценностным ориентиром экономических отношений, основой должной коммуникационной активности между различными субъектами экономических отношений и консолидацией общества для реализации цели создания условий для устойчивого экономического роста страны и повышения благосостояния граждан.

На основании вышеизложенного можно заключить, что конституционная реформа-2020 поставила и перед научным сообществом, и перед правоприменителями большое количество вопросов, связанных с определением идейно-ценностного содержания российской правовой системы. Если говорить лишь о конституционных принципах экономической системы, то, помимо институциональных принципов, появились иные коммуникативные принципы, представляющие собой основу непротиворечивости этических и правовых норм регулирования экономических отношений.

Представляется, что, безусловно, создание условий для устойчивого экономического роста страны и повышения благосостояния граждан, социальное партнерство, экономическая солидарность не являются такими же принципами права, как единство экономического пространства, свободное перемещение товаров, услуг и фринансовых средств и т. п., во-первых, в силу их текстуального расположения в Конституции России, поскольку они не являются основой конституционного строя, во-вторых, в силу невозможности проверки правовых актов на соответствие Конституции России, исходя из конкретного принципа, без выявления смысла иных принципов, 
составляющих основу конституционного строя. Однако в качестве конституционной ценности они закреплены и будут оказывать влияние на функционирование государства и общества современной России.

Экономическая солидарность представляет собой коммуникативный конституционный принцип, реализация которого в правовом пространстве будет носить абстрактный характер, что соответствует признакам конституционного принципа.

\section{Ссылки}

1. Данилина А. С., Бурзанов Ю. Л. Типология современных конституций в контексте равного компаративного достоинства для всех стран // Global \& Regional Research. 2020. T. 2, № 3. C. 129-133.

2. Слободчикова С. Н. К вопросу о конституционно-правовом понимании свободных выборов в России // Конституционное и муниципальное право. 2019. № 8. C. $46-49$.

3. Белов С. Ценности российской Конституции в тексте и в практике её толкования // Сравнительное конституционное обозрение. 2019. № 4 (131). С. 68-98.

4. Якимова Е. М. Концепция равновесия системы конституционного регулирования предпринимательской деятельности. М., 2020. 320 с.

5. Пьянов Н. А. Теория государства и права : учеб. пособие. Иркутск, 2014. 490 c.

6. Александров Ю. А. $\mathrm{K}$ вопросу о соотношении начал и принципов права // Baikal Research Journal. 2014. № 6. C. 27-29.

7. Чуксина В. В., Бондаренко О.В.Права человека в контексте политико-правовой турбулентности // Известия Байкальского государственного университета. 2017. T. 27, № 2. C. 218-230.

8. Бондарь Н. С. Конституционные ценности и политика: конституционализация политики, но не политизация конституционных ценностей // Журнал конституционного правосудия. 2016. № 1. С. 23-30.

9. Кистяковский Б. А. Государство правовое и социальное // Вопросы фрилософрии. 1990. № 6. С. 142-168.

10. Демидов А. И. Категория «политическая жизнь» как инструмент человеческого измерения политики // Полис. Политические исследования. 2002. № 3. C. $156-162$.

11. Жһалкиев В. Т. Проблема онтологического обоснования социальной солидарности // Общество и право. 2010. № 5 (32). С. 254-257.

12. Ивушкин А. С. Социально-экономические права в контексте теории публичного права Лона Фуллера и Джона Финниса // Теория и практика общественного развития. 2017. № 1. С. 132-134.

13. Кожемякина О. Н. Принцип солидарности в культуре доверия: социально-филлософский контекст // Studia Humanitatis. 2015. № 4. C. 19.

14. Алебастрова И. А. Принцип социальной солидарности в конституционном праве: дис. ... д-ра юрид. наук. М., 2016. 556 с.

15. Кузьменко И. С. К вопросу об исследовании солидарности в современной социальной науке // ПОИСК: Политика. Обществоведение. Искусство. Социология. Культура. 2019. № 6 (77). С. 84-90. 